\title{
PENGARUH EARNING PER SHARE, UKURAN PERUSAHAAN, DAN NET PROFIT MARGIN TERHADAP PRICE TO BOOK VALUE PADA PERUSAHAAN PERTAMBANGAN BATUBARA YANG TERDAFTAR DI BEI TAHUN 2012-2019
}

\author{
Bella Pradita Sari, Asep Muslihat* \\ Program Studi Akuntansi Fakultas Ekonomi Dan Bisnis, Universitas Singaperbangsa Karawang \\ *e-mail: bellapraditasari@gmail.com
}

\begin{abstract}
DiPublikasi: 01/01/2021
http://dx.doi.org/10.22225/kr.11.2.1154.190-196

Abstract

The study entitled "the effect of Earning Per Share, Firm Size, and Net Profit Margin against the Price to Book Value on the coal mining Companies registered in BEI 2012-2019". This type of research using a quantitative approach. The data used in this study is the annual financial report of the company coal mining sector registered in BEI 20122019. Data analysis used in this research is a multiple linear regression test. The results of the study found that earning per share has no effect on price to book value, firm size have an effect to price to book value, and net profit margin have an effect on price to book value.

Keywords: earning per share, firm size, net profit margin, price to book value

Abstrak

Penelitian ini berjudul "Pengaruh Earning Per Share, Ukuran Perusahaan, dan Net Profit Margin Terhadap Price to Book Value Pada Perusahaan Pertambangan Batubara Yang Terdaftar di BEI Tahun 2012-2019”. Jenis penelitian ini menggunakan pendekatan kuantitatif. Data yang digunakan dalam penelitian ini adalah laporan keuangan tahunan perusahaan pertambangan batubara yang terdaftar di BEI tahun 2012-2019. Alat analisis yang digunakan dalam penelitian ini adalah uji regresi linear berganda. Hasil penelitian menunjukkan bahwa earning per share tidak berpengaruh terhadap price to book value, ukuran perusahaan berpengaruh terhadap price to book value, dan net profit margin berpengaruh terhadap price to book value.
\end{abstract}

Kata Kunci : earning per share, ukuran perusahaan, net profit margin, price to book value

\section{PENDAHULUAN}

Indonesia memiliki sumber daya alam dan sumber daya manusia yang melimpah. Kekayaan alam yang melimpah tersebut dapat dimanfaatkan oleh masyarakat dan pemerintah untuk dikelola menjadi pertambangan. Indonesia memiliki wilayah tambang yang tersebar luas di berbagai daerah. Namun, dengan sumber daya alam yang mendukung tidak menjadikan daya saing pertambangan di Indonesia menjadi lebih baik dibanding dengan negara lain. Daya saing sektor pertambangan di Indonesia masih dibawah ratarata skor Asia yang artinya sektor pertambangan di Indonesia kurang kompetitif. Daya saing sektor pertambangan di Asia berada diangka 40-an sedangkan skor daya saing sektor pertambangan di Indonesia masih beradda dibawah angka 20 . Hal ini dapat diartikan bahwa kegiatan pertambangan di Indonesia masih rendah dan kurang kompetitif. Semakin dekatnya skor daya saing pertambangan diangka 100 maka mencerminkan bahwa sektor pertambangan di negara tersebut menarik dan berdaya saing tinggi.

Daya saing pertambangan Indonesia yang masih dibawah skor pertambangan di Asia tersebut membuat investor harus berhati-hati dalam melakukan investasi terutama di instrument keuangan saham. Saham memiliki resiko yang lebih besar dari instrument keuangan lain dikarenakan harga saham yang selalu fluktuatif disetiap waktu yang kemudian akan berakibat pada nilai price to book value di perusahaan. Kondisi yang seperti itu, dianjurkan untuk melakukan analisis terlebih dahulu perusahaan yang akan

Jurnal KRISNA: Kumpulan Riset Akuntansi Volume 12, Nomor 22021 CC-BY-SA 4.0 License

Page 218 
dipilih sehingga diharapkan akan dapat memberikan keuntungan di masa yang akan datang. Salah satu alat analisis yang biasa digunakan investor adalah analisis fundamental perusahaan yang didalamnya meliputi analisis rasio keuangan perusahaan dengan melihat laporan keuangan perusahaan.

\section{TINJAUAN PUSTAKA}

Menurut UU RI No. 4 Tahun 2009 tentang Pertambangan Mineral dan Batubara menyebutkan bahwa "Pertambangan adalah sebagian atau seluruh tahap kegiatan dalam rangka penelitian, pengelolaan dan pengusahaan mineral atau batubara yang meliputi penyelidikan umum, eksplorasi, studi kelayakan, konstruksi, penambangan, pengolahan dan pemurnian, pengangkutan san penjualan, serta kegiatan pascatambang."

Menurut Tandelilin (2017) earning per share merupakan informasi yang menunjukkan besarnya laba bersih yang siap dibagikan kepada semua pemegang saham di suatu perusaahaan.

Ukuran perusahaan adalah ukuran yang dapat mendefinisikan besar atau kecilnya suatu perusahaan yang dapat dilihat melalui rata-rata

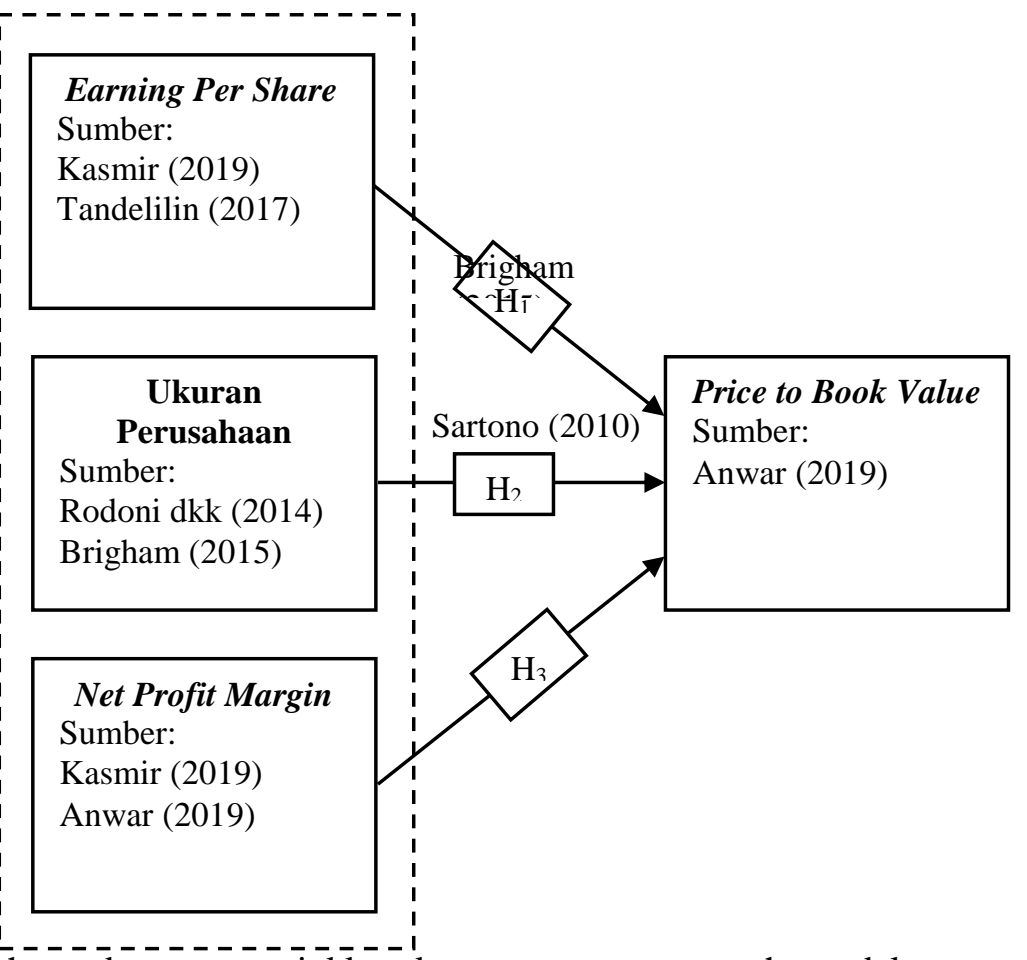

total penjualan bersih, dan jumlah aktiva yang dimiliki perusahaan serta dapat dihitung dengan cara $\ln$ (total aset).

Net profit magin adalah rasio atau alat hitung yang dapat menunjukkan kemampuan perusahaan dalam menghasilkan laba dengan cara membandingkan laba setelah bunga dan penjualan perusahaan.

Price to book value adalah rasio yang dapat menunjukkan harga suatu saham perusahaan apakah termasuk dalam kategori wajar, murah atau mahal. Rasio ini merupakan perbandingan harga saham dengan nulai buku perusahaan.

\section{Kerangka Berpikir}

Sumber: Kajian Peneliti, 2020

\section{Hipotesis:}

1. Earning Per Share

Semakin tinggi nilai earning per share yang dimiliki perusahaan maka akan semakin tinggi minat investor untuk melakukan pembelian saham karena laba yang akan diperoleh investor di setiap lembar sahamnya tinggi.

H1: earning per share berpengaruh terhaddap price to book value

\section{Ukuran Perusahaan}

Ukuran perusahaan menunjukkan besar atau kecilnya suatu perusahaan. semakin besar ukuran

perusahaan dapat menunjukkan kemampuan perusahaan dalam memunculkan dana yang lebih 
besar sehingga perusahaan dapat dengan mudah menjalankan usahanya untuk menghasilkan laba yang diminati investor. (Apsari, I., A., Dwiatmanto, \& Azizah, D., 2015)

\section{H2: ukuran perusahaan berpengaruh terhadap price to book value}

\section{Net Profit Margin}

Net profit margin merupakan rasio yang menunjukkan laba bersih yang dapat dihasilkan perusahaan. Semakin tinggi laba bersih yang dimiliki perusahaan maka semakin tinggi keuntungan yang akan diterima investor.

\section{H3: net profit margin berpengaruh terhadap price to book value}

\section{METODE PENELITIAN}

\section{Tempat, Obyek Penelitian, Populasi dan} Metode Penentuan Sampel

Tempat penelitian yang digunakan dalam penelitian ini adala Bursa Efek Indonesia. Objek penelitian yang digunakan dalam penelitian ini yaitu berupa laporan keuangan perusahaan dari periode 2012 sampai dengan periode 2019. Populasi perusahaan pertambangan sebanyak 23 perusahaan perusahaan pertambangan batubara yang terdaftar di Bursa Efek Indonesia dan sampel yang digunakan sebanyak 9 perusahaan pertambangan batubara yang terdaftar di Bursa Efek Indonesia periode 2012-2019. Metode pengumpulan data yang digunakan dalam penelitan ini adalah dengan menggunakan metode dokumentasi yang diperoleh dengan mendownload laporan keuangan perusahaan pertambangan batubara yang terdaftar di Bursa Efek Indonesia periode 2012-2019 melalui web resmi Bursa Efek Indonesia dan website resmi perusahaan pertambangan batubara.

Teknik pengambilan sampel dilakukan dengan teknik purposive sampling dimana sampel dipilih dengan kriteria-kriteria tertentu. Adapun kriteria-kriteria pengambilan sampel dalam penelitian ini adalah:

1. Perusahaan pertambangan subsektor batubara yang namanya secara berturut-turut terlisting di Bursa Efek Indonesia selama periode 2012-2019.

2. Perusahaan pertambangan subsektor batubara yang secara berturut-turut menerbitkan dan mempublikasikan laporan keuangan yang telah diaudit selama periode 2012-2019.

3. Perusahaan pertambangan subsektor batubara yang tidak mengalami kerugian secara berturut-turut selama periode 20122019.

\section{Data dan Sumber Data}

Penelitian ini menggunakan data sekunder yang artiya data yang digunakan diperoleh secara tidak langsung atau diperoleh dengan bentuk sudah jadi yang diperoleh dari orang lain. Penelitian ini menggunakan jenis data kuantitatif yaitu data yang dinyatakan dalam bentuk angka-angka. Sumber data yang digunakan didapatkan melalui website resmi perusahaan pertambangan batubara dan web resmi Bursa Efek Indonesia atau www.idx.co.id.

\section{Definisi Operasional Variabel dan Pengukurannya}

Variabel dependen dalam penelitian ini adalah earning per share, ukuran perusahaan, dan net profit margin perusahaan pertambangan batubara yang terdaftar di Bursa Efek Indonesia periode 2012-2019. Earning per share adalah rasio yang digunakan untuk melihat seberapa besar laba yang diperoleh pada setiap lembar saham biasa yang beredar (Tandelilin, 2017). Rasio ini dapat dihitung dengan menggunakan rumus sebagai berikut:

$$
\text { EPS }=\frac{\text { Laba bersih setelah bunga dan pajak }}{\text { Jumlah saham beredar }}
$$

Ukuran perusahaan menggambarkan besar atau kecilnya suatu perusahaan (Rodoni dkk, 2014). Untuk mengukur skala perusahaan dapat digunakan rumus sebagai berikut:

\section{Ukuran Perusahaan $=\ln ($ Total Assets $)$}

Net profit margin merupakan rasio yang dapat menunjukkan pendapatan bersih atas penjualan yang telah dilakukan perusahaan (Kasmir, 2019). Rasio ini dapat dihitung dengan menggunakan rumus sebagai berikut:

$$
\begin{array}{r}
\text { NPM }=\frac{\text { Earning After Interest and Tax (EAIT) }}{\text { Sales }} \times 100 \% \\
\text { Price to book value merupakan rasio }
\end{array}
$$
perbandingan harga pasar per lembar saham dengan nilai buku per lembar saham perusahaan (Anwar, 2019). Rasio ini dapat dihitung dengan menggunakan rumus sebagai berikut:

Price to Book Volue $=\frac{\text { Market Price per Share of Common Stock }}{\text { BookValue ver Shore of Common Stock }}$ 


\section{HASIL PENELITIAN DAN PEMBAHASAN Uji Normalitas}

Tabel 1.

Uji Normalitas

\begin{tabular}{|c|c|c|}
\hline \multicolumn{3}{|c|}{ One-Sample Kolmogorov-Smirnov Test } \\
\hline & & $\begin{array}{l}\text { Unstandard } \\
\text { ized } \\
\text { Residual }\end{array}$ \\
\hline \multicolumn{2}{|l|}{$\mathrm{N}$} & 72 \\
\hline \multirow{5}{*}{$\begin{array}{l}\text { Normal } \\
\text { Parameters }{ }^{\mathrm{a}} \\
\text { Most Extreme } \\
\text { Differences }\end{array}$} & Mean & .0000000 \\
\hline & Std. Deviation & .28252932 \\
\hline & Absolute & .098 \\
\hline & Positive & .098 \\
\hline & Negative & -.061 \\
\hline \multicolumn{2}{|c|}{ Kolmogorov-Smirnov Z } & .829 \\
\hline \multicolumn{2}{|c|}{ Asymp. Sig. (2-tailed) } & .498 \\
\hline
\end{tabular}

a. Test distribution is Normal.

Sumber: data diolah penulis, 2020

Dari hasil pengujian diatas dengan menggunakan uji Kolmogorov-smirnov, dapat diketahui bahwa nilai signifikansinya adalah 0,498 atau lebih dari $0,05(0,498>0,05)$, maka dapat disimpulkan bahwa data penelitian yang digunakan Analisis Regresi Linear Berganda dan Uji Parsial

Tabel 2.

Analisis Regresi Linear Berganda dan Uji Parsial

\section{dalam penelitian dan dapat dilanjutkan.}

\section{Coefficient}

\begin{tabular}{|c|c|c|c|c|c|}
\hline \multirow[b]{2}{*}{ Model } & \multicolumn{2}{|c|}{$\begin{array}{c}\text { Unstandardized } \\
\text { Coefficients }\end{array}$} & \multirow{2}{*}{$\begin{array}{c}\begin{array}{c}\text { Standardiz } \\
\text { ed } \\
\text { Coefficien } \\
\text { ts }\end{array} \\
\text { Beta }\end{array}$} & \multirow[b]{2}{*}{$\mathrm{T}$} & \multirow[b]{2}{*}{ Sig. } \\
\hline & B & Std. Error & & & \\
\hline 1 (Constant) & 1.454 & .575 & & 2.531 & .014 \\
\hline EPS & .434 & .561 & .093 & .775 & .441 \\
\hline SIZE & -.069 & .029 & -.280 & -2.339 & .022 \\
\hline NPM & .017 & .006 & .332 & 2.739 & .008 \\
\hline
\end{tabular}

a. Dependent Variable: PBV

Sumber: data diolah, 2020

Berdasarkan hasil analisis reoresi linear heroanda (multiple linear regression) seperti vang 
disajikan pada tabel diatas dapat diketahui persamaan analisis regresi linear bergandanya sebagai berikut:

$$
\begin{aligned}
& Y=\alpha+\beta 1 X 1+\beta 2 X 2+\beta 3 X 3+e \\
& Y=1,454+0,434 X_{1}-0,069 X_{2}+0,17 X_{2}+e
\end{aligned}
$$

Keterangan:

$$
\begin{aligned}
& \mathrm{Y}=\text { Price to book value } \\
& \alpha=\text { Konstanta } \\
& \beta=\text { Koefisien regresi model } \\
& X 1=\text { Earning per share } \\
& X 2=\text { Ukuran perusahaan } \\
& X 3=\text { Price to book value } \\
& \mathrm{e}=\text { error term model }
\end{aligned}
$$

Angka-angka tersebut dapat diartikan sebagai berikut:

1. Koefisien Regresi Model

a. Nilai konstanta sebesar 1,454 berarti bahwa jika earning per share, ukuran perusahaan dan net profit margin perusahaan bernilai 0 , maka price to book value akan bernilai 1,454 .

b. Nilai koefisien regresi earning per share sebesar 0,434 berarti bahwa jika earning per share terjadi kenaikan satu poin, maka nilai price to book value perusahaan akan naik sebesar 0,434 atau sebaliknya.

c. Nilai koefisien ukuran perusahaan sebesar -0,069 berarti bahwa jika ukuran perusahaan terjadi kenaikan satu poin, maka nilai price to book value perusahaan akan mengalami penurunan sebesar 0,069 atau sebaliknya.

d. Nilai koefisien regresi net profit margin sebesar 0,017 berarti bahwa jika net profit margin terjadi kenaikan satu poin, maka nilai price to book value perusaahaan akan mengalami kenaikan sebesar 0,017 atau sebaliknya.

2. Pengaruh variabel secara parsial (Analisis ttest)
Kriteria pengujian untuk menjelaskan interpretasi pengaruh antar masing-masing variabel earning per share, ukuran perusahaan, dan net profit margin terhadap price to book value sebagai berikut:

Jika Sig $\mathrm{t}<0,05$ maka $\mathrm{H}_{0}$ ditolak dan $\mathrm{H}_{\mathrm{a}}$ diterima.

Jika Sig. $\mathrm{t}>0,05$ maka $\mathrm{H}_{0}$ diterima dan $\mathrm{H}_{\mathrm{a}}$ ditolak.

a. Pengaruh earning per share terhadap price to book value

Berdasarkan hasil analisis pengaruh earning per share terhadap price to book value diperoleh nilai Sig. $\mathrm{t}$ sebesar 0,441 dengan nilai t hitung sebesar 0,775. Nilai Sig. t 0,441 > 0,05 mengindikasikan bahwa $\mathrm{H}_{0}$ diterima dan $\mathrm{H}_{\mathrm{a}}$ ditolak yang berarti bahwa variabel earning per share tidak berpengaruh terhadap price to book value.

b. Pengaruh ukuran perusahaan terhadap price to book value

Berdasarkan hasil analisis pengaruh ukuran perusahaan terhadap price to book value diperoleh nilai Sig. $\mathrm{t}$ sebesar 0,022 dengan nilai t hitung sebesar -2,33. Nilai Sig. t 0,022 < 0,05 mengindikasikan bahwa $\mathrm{H}_{0}$ ditolak dan $\mathrm{H}_{2}$ diterima yang berarti bahwa variabel ukuran perusahaan berpengaruh negatif dan signifikan terhadap price to book value.

c. Pengaruh net profit margin terhadap price to book value

Berdasarkan hasil analisis pengaruh net profit margin terhadap price to book value diperoleh nilai Sig. $\mathrm{t}$ sebesar 0,008 dengan nilai t hitung 2,73. Nilai Sig. t $0,008<0,05$ mengindikasikan bahwa $\mathrm{H}_{0}$ ditolak dan $\mathrm{H}_{3}$ diterima yang berarti bahwa variabel net profit margin berpengaruh positif dan signifikan terhadap price to book value. 


\section{Koefisien Determinasi}

Tabel 3.

Koefisien Determinasi

\begin{tabular}{|l|r|r|r|r|r|}
\hline Model & \multicolumn{1}{|c|}{$\mathrm{R}$} & R Square & $\begin{array}{c}\text { Adjusted R } \\
\text { Square }\end{array}$ & $\begin{array}{c}\text { Std. Error of } \\
\text { the Estimate }\end{array}$ & $\begin{array}{c}\text { Durbin- } \\
\text { Watson }\end{array}$ \\
\hline 1 & $.384^{\mathrm{a}}$ & .147 & .110 & .28869 & 1.439 \\
\hline
\end{tabular}

a. Predictors: (Constant), NPM, SIZE, EPS

b. Dependent Variable: PBV

Sumber: data diolah penulis, 2020

Berdasarkan hasil pengolahan data diatas, dapat diketahui bahwa nilai $\mathrm{R}$ square sebesar 0,110 atau $11 \%$. Hal ini menunjukkan bahwa variabel yang diteliti yaitu earning per share, ukuran perusahaan, dan net profit margin berpengaruh sebesar $11 \%$ terhadap price to book value. Sedangkan sisanya sebesar $89 \%$ dipengaruhi oleh variabel yang tidak termasuk dalam penelitian ini.

\section{Uji Simultan (Uji-F)}

Tabel 4.

Uji Simultan (Uji-F)

\section{ANOVA $^{b}$}

\begin{tabular}{|c|c|c|c|c|c|}
\hline Model & $\begin{array}{l}\text { Sum of } \\
\text { Squares }\end{array}$ & Df & Mean Square & $\mathrm{F}$ & Sig. \\
\hline Regression & .979 & 3 & \multirow{3}{*}{$\begin{array}{l}.326 \\
.083\end{array}$} & \multirow[t]{3}{*}{3.914} & \multirow[t]{3}{*}{$.012^{\mathrm{a}}$} \\
\hline Residual & 5.667 & 68 & & & \\
\hline Total & 6.646 & 71 & & & \\
\hline
\end{tabular}

a. Predictors: (Constant), NPM, SIZE, EPS

b. Dependent Variable: PBV

Sumber: data diolah penulis, 2020

Pengujian hipotesis menggunakan uji f yaitu dengan membandingkan $\mathrm{f}$ hitung dengan $\mathrm{f}$ tabel pada $\alpha=0,05$ dengan rumus $\mathrm{df}_{1}=3$ dan $\mathrm{df}_{2}=\mathrm{n}-\mathrm{k}=72$ $3=69$ maka $f$ tabel didapat $F(3 ; 69)$ dimana $n$ merupakan jumlah sampel dan $\mathrm{k}$ merupakan variabel independen dengan kriteria keputusan sebaagai berikut:

Jika sig $>\alpha$ atau $\mathrm{t}$ hitung $<\mathrm{t}$ tabel maka $\mathrm{H}_{0}$ diterima atau $\mathrm{H}_{\mathrm{a}}$ ditolak

Jika sig $<\alpha$ atau $\mathrm{t}$ hitung $>\mathrm{t}$ tabel maka $\mathrm{H}_{0}$ ditolak atau $\mathrm{H}_{\mathrm{a}}$ diterima

Berdasarkan hasil analisis pengaruh earning per share, ukuran perusahaan, dan net profit margin terhadap price to book value didapatkan bahwa nilai sig.f sebesar 0,012 dan nilai f hitung sebesa 3,914. bahwa secara bersama-sama variabel earning per share, ukuran perusahaan, dan net profit margin berpengaruh terhadap price to book value perusahaan pertambangan batubara.

\section{Pembahasan}

Berdasarkan hasil uji hipotesis yang telah dilakukan diatas dapat dijelaskan sebagai berikut:

1. Hasil pengujian earning per share (X1) tidak memiliki pengaruh terhadap price to book value dikarenakan laba per lembar saham yang akan diberikan investor memiliki nilai yang kecil sehingga nilai price to book value tidak mengalami peningkatan penelitiaan ini sejalan dengan penelitian yang telah dilakukan oleh (Furniawan, 2019) 
2. Hasil pengujian ukuran perusahaan (X2) menyatakan bahwa ukuran perusahaan memiliki pengaruh terhadap price to book value. Hal ini dikarenakan semakin besar perusahaan maka perusahaan dapat dengan mudah mendapatkan modal untuk meningkatkan laba melalui ekspansi penelitian ini sejalan dengan penelitian yang telah dilakukan oleh (Angesti, 2019)

3. Hasil pengujian net profit margin (X3) terdapat pengaruh terhadap price to book value dikarenakan semakin besar marjin laba bersih

\section{KESIMPULAN DAN SARAN Simpulan}

Hasil pengujian yang diteliti menunjukkan bahwa data yang digunakan dalam penelitian ini telah memnuhi syarat kelayakan dalam pengujian. Adapun hasil pengujian model regresi dengan analisis regresi linear berganda dapat digunakan untuk mengju hipotesis dan didapatkan hasil bahwa

1. Variabel earning per share tidak berpengaruh terhadap price to book value.

2. Variabel ukuran perusahaan berpengaruh terhadap price to book value.

3. Variabel net profit margin berpengaruh terhadap price to book value.

4. Variabel earning per share, ukuran perusahaan, dan net profit margin secara bersama-sama berpengaruh terhadap price to book value.

\section{DAFTAR PUSTAKA}

Angesti, A. (2019). Pengaruh Capital Turnover, Return on Equity, dan Firm Size terhadap Price Book Value. Jurnal Ekonomi \& Ekonomi Syariah, 2, 2.

Apsari, I., A., Dwiatmanto, \& Azizah, D., F. (2015). Pengaruh Return On Equity, Net Profit Margin, Debt To Equity yang dimiliki perusahaan menandakan bahwa perusahaan tersebut dapat terus berkembang dan diharapkan return yang diterima investor lebih besar penelitian ini sejalan dengan penelitian yang telah dilakukan

4. Hasil pengujian earning per share, ukuran perusahaan, dan net profit margin secara bersama-sama memiliki pengaruh terhadap price to book value perusahaan pertambangan batubbara. Penelitian ini sejalan dengan penelitian yang telah dilakukan

\section{Saran}

Berdasarkan simpulan yang telah dijelaskan diatas, penelitian ini dapat memberikan saran-saran sebagai berikut:

1. Hasil penelitian ini tidak dapat di generalisir terhadap penelitian serupa karena penelitian ini hanya dilakukan pada perusahaan perusahaan pertambangan batubara.

2. Bagi peneliti selanjutnya disarankan untuk menambah variabel dan memperluas sampel penelitian serta memilih rentang tahun yang lebih panjang sehingga diharapkan dapat memperoleh hasil penelitian yang lebih akurat.

Ratio, Dan Longterm Debt To Equity Ratio Terhadap Price Book Value. Jurnal Administrasi Bisnis, 27, 2.

Furniawan. (2019). Pengaruh Earning Per Share, Debt To Asset Ratio, Debt To Equity Ratio Dan Return On Equity Terhadap Price To Book Value. The Asia Pasific Journal of Management, 6, 3. 